\title{
REVIEW
}

\section{Seagrass herbivory: evidence for the continued grazing of marine grasses}

\author{
John F. Valentine*, K. L. Heck, Jr \\ 101 Bienville Boulevard, Dauphin Island Sea Lab, Dauphin Island, Alabama 36528-0369, USA \\ and \\ Department of Marine Science, University of South Alabama, Mobile, Alabama 36688-0002, USA
}

\begin{abstract}
Unlike the majority of marine plants, seagrasses are believed to experience little damage from the feeding activities of marine herbivores. Based on our previous work, plus a review of the literature, we suggest that this paradigm significantly underestimates the importance of seagrass herbivory in nearshore environments. In this review, we provide evidence from over 100 publications, showing that grazing on seagrasses is widespread in the world's oceans. Overwhelmingly, reports of grazing on seagrasses are based on observations, laboratory measurements, and bioenergetic calculations. To date, few field experiments have been conducted to evaluate the importance of seagrass grazing in the nearshore environment. Of these, even fewer have considered the possibility that herbivores may stimulate rates of primary production of the role of belowground nutrient reserves in determining the impacts of grazers on seagrasses. We contend that the currently accepted view that herbivory plays a minor role in the energetics of seagrass habitats needs to be reexamined by measuring seagrass responses to grazer induced tissue losses in controlled field manipulations. Only then will we be able to determine the importance of the seagrass-grazing pathway in marine food webs.
\end{abstract}

KEY WORDS: Seagrass - Herbivory - Waterfowl · Fishes - Sea urchins · Food webs

\section{INTRODUCTION}

Herbivores often greatly influence the productivity and abundance of plants in aquatic and marine environments (e.g. Porter 1973, 1977, Lynch \& Shapiro 1981, Lewis 1985, Vanni 1987a, Mallin \& Paerl 1994). For example, in freshwater lakes, zooplankton grazing can reduce the abundance of small or naked phytoplankton species, favoring the survival of larger phytoplankton species with gelatinous sheaths or other structures that reduce their vulnerability to grazing (e.g. Porter 1973, 1977, McCauley \& Briand 1979, Demott \& Kerfoot 1982, Vanni 1987b). In marine

-Address for correspondence: Marine Environmental Sciences Consortium, 101 Bienville Boulevard, Dauphin Island Sea Lab, Dauphin Island, Alabama 36528-0369, USA.

E-mail: jvalenti@jaguar1.usouthal.edu environments, grazing by coral reef fishes and invertebrates can cause shifts in macroalgal community structure from dominance by highly competitive, fastgrowing, edible algae to competitively inferior, slower growing, but chemically defended algae (reviewed by Hay \& Steinberg 1992). Similarly, gastropod grazing can alter macroalgal community structure in temperate rocky intertidal zones by removing competitively dominant, fast-growing, more palatable species, which are then replaced by competitively inferior, slower growing, less palatable species (reviewed by Lubchencho \& Gaines 1981, Gaines \& Lubchencho 1982). In one of the most dramatic examples of herbivore impacts on primary producers, sea urchin grazing can convert macroalgal kelp forests to grazer resistant coralline dominated algal pavements in temperate and boreal settings (reviewed by Lawrence 1975). 


\section{The seagrass-detritus paradigm}

In contrast, marine vascular plants or seagrasses, which are common in coastal waters along every continent except Antarctica, are reported to experience very low levels of herbivory because their leaves are thought to be of poor nutritional value, owing to high C/N ratios (e.g. Bjorndal 1980, Duarte 1990, Lalli \& Parsons 1993, Valiela 1995), and the inability of most invertebrate grazers to digest cellulose (Lawrence 1975). Current levels of seagrass herbivory are also thought to be low because of the historical overharvesting of larger vertebrate herbivores (e.g. green turtles, dugongs, manatees, fishes, and waterfowl; Randall 1965, Heinsohn \& Birch 1972, Lipkin 1975, Charman 1979, Bjorndal 1980, Kiorboe 1980, Jacobs et al. 1981., Thayer et al. 1984, Dayton et al. 1995). As a result, the amount of seagrass production entering food webs via grazing is believed to be small, usually less than $10 \%$ of annual net aboveground primary production, with most macrophyte production thought to enter food webs through the detrital pathway (e.g. Fenchel 1970, 1977, Kikuchi \& Peres 1977, Nienhaus \& Van lerland 1978, Kikuchi 1980, Thayer et al. 1984, Nienhaus \& Groenendijk 1986, Zieman \& Zieman 1989). Consequently, investigations of the factors controlling seagrass growth and biomass have emphasized the primacy of nutrient supply (e.g. Patriquin 1972, Short 1987, Powell et al. 1989, Fourqurean et al. 1992, Short et al. 1993), light availability, and/or physical factors (e.g. Patriquin 1975, Backman \& Barilotti 1976, Dennison \& Alberte 1985, Thom \& Albright 1990)

\section{COUNTER EVIDENCE}

There are, however, few actual tests of this paradigm, and there is an existing body of evidence which shows that its underlying assumptions need reevaluation. For example, several investigators have provided evidence that nitrogen concentrations in seagrasses are similar to those of algae (e.g. Lowe \& Lawrence 1976, Lobel \& Ogden 1981, reviewed in Thayer et al. 1984). There is also substantial evidence that detrital seagrass leaves are an even poorer source of nutrition (i.e. have higher $\mathrm{C} / \mathrm{N}$ ratios) for consumers than are living leaves (Klumpp \& Van der Walk 1984), as seagrass detritus resists decay, requiring long periods of conditioning time before detritivores can use it (Harrison \& Mann 1975, Zieman 1975, Fenchel 1977. Thayer et al. 1977, Rice 1982).

In addition, many herbivorous fishes are 'extreme' generalists that feed on vegetation in proportion to its abundance (Ogden 1980, Hay \& Steinberg 1992, Hay
1997). In fact, field palatability testing using both seagrasses and marine macroalgae has found that seagrasses are of intermediate palatability among several species of algae offered to marine herbivores throughout the Caribbean Sea and Indian Ocean (e.g. Hay 1981, 1984a, b, Lewis 1985, Maclntyre et al. 1987). If true, seagrasses are likely to contribute to the diets of many of marine herbivorous fishes in some significant way.

More importantly, we and others have shown, from field observations and short-term experiments, that the variegated sea urchin Lytechinus variegatus (Lamarck) consumes from 50 to $100 \%$ of the aboveground seagrass biomass produced in some areas of the eastern Gulf of Mexico and Caribbean Sea (Moore et al. 1963, Camp et al. 1973, Greenway 1976, 1995, Zimmerman \& Livingston 1976, Bach 1979, Valentine \& Heck 1991, Heck \& Valentine 1995). At densities of 10 ind. $\mathrm{m}^{-2}, L$. variegatus can reduce turtlegrass habitats to barren unvegetated substrates from fall through early spring (Valentine \& Heck 1991). If grazing is persistent throughout the winter and spring, sea urchins can reduce these vegetated habitats to permanently barren unvegetated substrates (Heck \& Valentine 1995). In suramer, turtlegrass persists under severe grazing pressure and regrows to levels that either equal or exceed the standing crop of nearby ungrazed turtlegrass. The apparent mechanism by which turtlegrass overcomes the effects of this grazing is to increase the production or recruitment of new shoots in the grazed area rather than to increase the production of existing shoots (Valentine et al. 1997). Similarly, the sea urchins Tripneustes ventricosus can, and Diadema antillarum did, until recently, consume large quantities of seagrass in some Caribbean settings (e.g. Ogden et al. 1973, Lilly 1975, Vicente \& Rivera 1982, Keller 1983, Tertschnig 1984 in Tertschnig 1989). Although it was once thought that grazing on seagrasses was predominantly a Caribbean phenomenon (Ogden \& Zieman 1977, Ogden 1980, Ogden \& Ogden 1982), observations elsewhere show that sea urchins also consume significant amounts of seagrass in the tropical Pacific and Indian Oceans (Bak \& Nojima 1980, Kirkman \& Young 1981, Hulings \& Kurkman 1982, Verlaque \& Nedelec 1983, Jafari \& Mahasneh 1984, Larkum \& West 1990, Klumpp et al 1993, Jernakoff et al. 1996).

In tropical settings where fishing pressure is low, herbivorous fish, not sea urchins, are the dominant herbivores (e.g Ogden 1976, 1980, Hay 1981, 1984a, Carpenter 1986, but see Jackson 1997). More than 30 species of Caribbean fishes, predominantly parrotfishes and surgeonfishes, have been found with seagrasses in their guts (Randall 1967, McAfee \& Morgan 1996, Lewis \& Wainwright 1985, but see Hay 1984a). It is likely that even more species draw nutrition from 
these plants, as investigators have typically considered the presence of seagrass leaves in the guts of fishes to be incidental intake associated with the capture of animal prey (e.g. Thompson 1959, Carr \& Adams 1973, Bell et al. 1978). When seagrass leaves are isotopically labeled or fishes have been presented with seagrass in laboratory studies, it has been found that seagrasses leaves can contribute to fish growth (e.g. Conacher et al. 1979, Montgomery \& Targett 1992). Using stable isotopes, Fry et al. (1982) found that seagrasses and benthic algae contributed significantly to the diets of many fishes in the seagrass beds of St. Croix, USVl. Fry \& Parker (1979) also found that seagrasses and other benthic plants contributed significantly to the diets of shrimps and fishes in some areas of Texas.

In some locations, fish grazing on seagrasses is so intense that 'halos' are created and maintained within seagrass habitats at the base of coral reefs (e.g. Randall 1965, Ogden \& Zieman 1977, Hay 1984a, McAfee \& Morgan 1996). Not all foraging in and on seagrasses is near the base of coral reefs, however (Ogden \& Zieman 1977). While many herbivorous fishes seek shelter on coral reefs at night, they commonly forage in nearby seagrass habitats throughout the day (Randall 1965, Ogden \& Zieman 1977, Zieman et al. 1984, McAfee \& Morgan 1996). For example, the parrotfish Scarus guacamaia and $S$. coelestinus have been reported to move up to $500 \mathrm{~m}$ inshore from coral reefs to feed (Winn \& Bardach 1960, Winn et al, 1964). Juvenile and smaller species of parrotfish also feed on seagrasses away from the reef (Ogden \& Zieman 1977. Handley 1984, MacIntyre 1987, McGlathery 1995, McAfee \& Morgan 1996). Once large enough, many juvenile fish abandon structurally simpler seagrass habitats for more structurally complex coral reefs where it has been hypothesized that they find increased protection from large piscivorous fishes (Springer \& McErlean 1962, Ogden \& Zieman 1977. Dubin \& Baker 1982, Handley 1984, Carpenter 1986). These observations suggest that the flow of energy from seagrass habitats to coral reefs can be substantial, but quantitative estimates are constrained by the limited amount of information on coral reef food webs (cf. Polunin 1996).

Investigators have used tethering, stable isotope, gut content studies, and reconstructive sampling techniques to show that seagrasses are readily consumed by fishes, at times in large quantities, in some areas of the Mediterranean Sea, the Indian and Pacific Oceans (Kirkman \& Reid 1979, Hay 1981, 1984a, b, Klumpp \& Nichols 1983a, b, Lewis 1985, Nichols et al. 1985, Nojima \& Mukai 1990, Cebrián et al. 1996a, b, Pinto \& Punchihewa 1996, Marguillier et al. 1997). In virtually every study seagrass leaves were readily consumed by herbivores, thereby demonstrating the susceptibility of seagrasses to herbivores across broad geographic areas. We have so far emphasized the importance of sea urchin and fish grazing on seagrasses, but several species of waterfowl have also been shown to consume large quantities of seagrass production (both aboveand belowground) during their seasonal migrations through subtropical, temperate and boreal estuaries (e.g. Charman 1977, Wilkins 1982, Tubbs \& Tubbs 1983, Baldwin \& Lovvorn 1994, Michot \& Chadwick 1994. Mitchell et al. 1994). In addition, green turtles Chelonia mydas (Linnaeus) and sirenians (manatees and dugongs), which are still abundant in some areas, are intense seagrass grazers (Heinsohn \& Birch 1972 , Spain \& Heinsohn 1973, Lipkin 1975, Heinsohn et al. 1976, Anderson \& Birtles 1978, Nietschmann \& Nietschmann 1981, Marsh et al. 1982, Ogden et al. 1983, Nishiwaki \& Marsh 1985, Lanyon et al. 1989, Nietschmann 1990, Provancha \& Hall 1991, de Iongh et al. 1995, Preen 1995). These large herbivores can have even greater impacts on seagrass productivity and abundance than sea urchins or fishes (Zieman et al. 1984). All of the examples cited above show that seagrass herbivory, although probably reduced in a historical context, continues to represent an important and underestimated trophic pathway in many areas, and not a highly localized anomalous event.

\section{SEAGRASS-HERBIVORE INTERACTIONS}

If this view is correct, how do seagrasses persist in the face of such grazing pressure? We believe that part of the answer lies in the unrecognized potential of seagrasses to compensate for grazing losses, and the belowground location of much seagrass biomass. During the summer months we have shown that turtlegrass responds to sea urchin grazing by increasing the production of new shoots, which leads to increased areal aboveground primary production (Valentine et al. 1997). Because of the increased production of new shoots, aboveground biomass in grazed areas does not change when compared to nearby ungrazed plots during the growing season. We suggest that this increased turnover of leaf material allows seagrasses to compensate for tissue lost to herbivores and enables seagrass to persist during intense grazing (Valentine et al. 1997). Since new shoots are produced only at rhizome apices (Tomlinson \& Vargo 1966), we hypothesized that sea urchin grazing should also lead to increased belowground production (Valentine et al. 1997). Our data suggest that focussing solely on seagrass biomass without accounting for the material produced between sampling periods can lead to large underestimates of the amount of seagrass consumed by herbivores (cf. Jacobsen \& Sand-Jensen 1994, Sand-Jensen et al. 1994) 
Table 1. Summary of selected studies or reports of herbivory in seagrasses. W: waterfowl; U: urchin; G: gastropod; C: crustacean; F: fish; $R$ : reptile; $M$ : mammal

\begin{tabular}{|c|c|c|c|}
\hline Grazer & Seagrass, location, study type & Description of results & Source \\
\hline $\begin{array}{l}\text { Branta bernicla bernicla (W), } \\
\text { Anas penelope (W). Anas } \\
\text { crecca (W) }\end{array}$ & $\begin{array}{l}\text { Zostera noltii and } Z \text {. matina. Solent, England. } \\
\text { Field study, percent cover recorded at } 5 \\
\text { stations. Exclosures used to monitor seagrass } \\
\text { change due to grazing. }\end{array}$ & $\begin{array}{l}\text { Large reductions in seagrass areal coverage } \\
\text { attributed to brent geese feeding. }\end{array}$ & $\begin{array}{l}\text { Tubbs \& Tubbs } \\
\text { (1983) }\end{array}$ \\
\hline $\begin{array}{l}\text { B. bernicla (W), A. acuta (W) } \\
\text { A. penelope (W), A. } \\
\text { platyrhyncha (W) }\end{array}$ & $\begin{array}{l}\text { Z. noltii and } Z \text { marina. Dutch Wadden Sea. } \\
\text { Field-based bioenergetic study and field ex- } \\
\text { periment where change in submerged aquatic } \\
\text { vegetation (SAV) shoot density, biomass, and } \\
\text { percent cover were monitored. }\end{array}$ & $\begin{array}{l}\text { An estimated } 1426 \mathrm{~kg} \mathrm{DW} \text { of seagrass }(-50 \% \text { of } \\
\text { ail } \mathrm{SAV} \text { production) consumed, mostly by } \mathrm{A} \text {. acuta } \\
\text { and } \mathrm{A} \text {. penelope. }\end{array}$ & Jacobs et al. (1981\}) \\
\hline $\begin{array}{l}\text { B. bernicla (W), Anas } \\
\text { americana (W), A. platy- } \\
\text { rhynchos (W). A. acuta (W) }\end{array}$ & $\begin{array}{l}\text { Zostera japonica and } Z \text {. marina. Boundary } \\
\text { Bay, British Columbia. Collections and field } \\
\text { based bioenergetic study. Above- and below- } \\
\text { ground standing stock were monitored. Water- } \\
\text { lowl use days were estimated. Some birds were } \\
\text { collected and esophagus contents recorded. }\end{array}$ & $\begin{array}{l}\text { Bird density positively correlated with SAV } \\
\text { distribution. Dabbling ducks and geese consumed } \\
\text { some } 362 \mathrm{t} \text { of } Z \text {. japonica leaves and rhizomes } \\
(-50 \% \text { of aboveground and } 43 \% \text { of belowground } \\
\text { biomass) at the study site. Lesser amounts of } \\
Z \text {. marina consumed. }\end{array}$ & $\begin{array}{l}\text { Baldwin \& } \\
\text { Lovvorn (1994) }\end{array}$ \\
\hline Aythya americana (W) & $\begin{array}{l}\text { Halodule wrightii. Lower Laguna Madre, TX. } \\
\text { Two years of field collections and } 1 \text { experi- } \\
\text { ment at } 3 \text { sites were used to assess impacts of } \\
\text { redhead ducks on SAV biomass. }\end{array}$ & $\begin{array}{l}\text { Rhizome biomass was } 75 \% \text { lower in grazed areas } \\
\text { than where grazers were excluded. When rhizome } \\
\text { biomass was grazed below } 0.18 \mathrm{~g} \mathrm{DM} M^{-1} \text { core }{ }^{-1} \text { (at } \\
1 / 3 \text { of the sites), grass did not recover. }\end{array}$ & $\begin{array}{l}\text { Mitchell et al. } \\
\text { (1994) }\end{array}$ \\
\hline $\begin{array}{l}\text { B. bernicla (W), Anas } \\
\text { penelope (W). A. crecca (W) }\end{array}$ & $\begin{array}{l}\text { Zostera noltii and Zostera marina. Dutch } \\
\text { Wadden Sea. Field surveys plus an exclosure } \\
\text { experiment were used to quantify impacts of } \\
\text { wildfowl grazing on seagrass biomass. }\end{array}$ & $\begin{array}{l}\text { Brent geese and widgeon reduced aboveground } \\
\text { biomass some } 30 \% \text { faster than in areas where } \\
\text { grazers were excluded. Belowground biomass in } \\
\text { grazed cages was } 48 \% \text { lower than in ungrazed plots. }\end{array}$ & Madsen (1988) \\
\hline $\begin{array}{l}\text { Cygnus olor (W), Anas } \\
\text { penelope (W), A platyrhyn- } \\
\text { chos (W), A. acuta (W), A. } \\
\text { creeca (W), Aythya ferina (W), } \\
\text { Branta bernicla (W), Fulica } \\
\text { atra (W), Idotea chelipes (C) }\end{array}$ & $\begin{array}{l}\text { Zostera marina. Lake Grevelingen, SW } \\
\text { Netherlands. Field-based bioenergetic study } \\
\text { and laboratory experiment. }\end{array}$ & $\begin{array}{l}\text { An estimated } 7.5 \% \text { of Zostera marina production } \\
\text { consumed by waterfowl and a single species of } \\
\text { isopod. }\end{array}$ & $\begin{array}{l}\text { Nienhuis \& } \\
\text { Groenendijk } \\
\text { (1986) }\end{array}$ \\
\hline $\begin{array}{l}\text { Branta bernicla hrota }(\mathrm{W}) \\
\text { Anas penelope }(\mathrm{W})\end{array}$ & $\begin{array}{l}\text { Zostera sp. Strangford Slough, Northern } \\
\text { Ireland. Field study. The impact of grazers } \\
\text { was documented by monitoring changes in } \\
\text { seagrass biomass at the study area along with } \\
\text { the use of exclusion cages in grassbeds with } \\
\text { uniform coverage. }\end{array}$ & $\begin{array}{l}\text { Grazing led to faster rates of seagrass loss than } \\
\text { was occurring due to weathering in ungrazed } \\
\text { areas. Belowground biomass was } 48 \% \text { lower in } \\
\text { grazed plots than measured in ungrazed plots. }\end{array}$ & Portig et al. (1994) \\
\hline Aythya americana (W) & $\begin{array}{l}\text { Halodule wrighti. Chandeleur Sound, LA. } \\
\text { Field monitoring of seagrass biomass to } \\
\text { document the impact of waterfowl grazing on } \\
\text { seagrass. }\end{array}$ & $\begin{array}{l}\text { Waterfowl grazing was found to reduce above- } \\
\text { ground and belowground biomass by } 90 \text { and } 49 \% \\
\text { respectively. }\end{array}$ & $\begin{array}{l}\text { Michot \& Chad- } \\
\text { wick (1994) }\end{array}$ \\
\hline Lytechinus varjegatus $\{\mathrm{U}\}$ & $\begin{array}{l}\text { Thalassia testudinum. Miskito Cays, } \\
\text { Nicaragua. Laboratory measurements, field } \\
\text { collections and observations. Feeding } \\
\text { preferences determined by turning over } \\
\text { urchins. Urchin gut contents examined at } \\
1 \text { station. }\end{array}$ & $\begin{array}{l}\text { Sea urchins were estimated to consumed some } 0.5 \\
\text { g DW per urchin } d^{-1} \text { of seagrass. However, gut } \\
\text { contents indicated that } 40 \% \text { of this urchin's diet } \\
\text { was detrital turtlegrass. Less than } 5 \% \text { of the diet } \\
\text { was live grasses. }\end{array}$ & Vadas et al. (1982) \\
\hline $\begin{array}{l}\text { L. vanegatus }(\mathrm{U}) \text {, Sparisoma } \\
\text { radians }(\mathrm{F}), \text { Archosargus } \\
\text { rhomboides }(\mathrm{F}) \text {, Monocanthus } \\
\text { setiferus }(\mathrm{F}) \text {. Acanthurus } \\
\text { chirurigus }(\mathrm{F}) \text {. Sphaeroides } \\
\text { spengleri }(\mathrm{F}) \text {. Acan- } \\
\text { thostracion quadriconis }(\mathrm{F})\end{array}$ & $\begin{array}{l}\text { Thalassia testudinum. Kingston Harbour, } \\
\text { Jamaica. Laboratory measurements, field } \\
\text { sampling, stomach content analysis, and field } \\
\text { experimentation to estimate herbivory on } \\
\text { grazers on seagrass. }\end{array}$ & $\begin{array}{l}5 \text { species of fish found to feed on both live and detrital } \\
\text { seagrass along with algae and crustaceans. Only the } \\
\text { sea urchin Lytechinus and the bucktooth parrotfish } S \text {. } \\
\text { radians were found to feed predominantly on sea- } \\
\text { grass. Lytechinus was estimated to consume some } \\
49 \% \text { of the SAV leaf tissue produced each day. A } \\
\text { small fraction of this production was consumed by } \\
\text { fishes. }\end{array}$ & $\begin{array}{l}\text { Greenway }(1975, \\
1995)\end{array}$ \\
\hline L. variegatus $(\mathrm{U})$ & $\begin{array}{l}\text { Thalassia testudinum. Offshore grass beds of } \\
\text { west Florida. Field observations and } \\
\text { measurements. }\end{array}$ & $\begin{array}{l}\text { An episodic settlement of sea urchins led to } \\
\text { significant reductions of seagrass coverage. } \\
\text { Grazing was found to have denuded an estimated } \\
20 \text { ha area of seagrass habitat. }\end{array}$ & Camp et al. (1973) \\
\hline $\begin{array}{l}\text { L. variegatus (U), Tripneustes } \\
\text { ventricosus (U) }\end{array}$ & $\begin{array}{l}\text { Thalassia testudinum. Discovery Bay, } \\
\text { Jamaica. Field experiment tested for } \\
\text { intraspecific and interspecific competition } \\
\text { between } 2 \text { species of urchins. Aboveground } \\
\text { biomass within cages was used to document } \\
\text { the effects of urchin manipulations. }\end{array}$ & $\begin{array}{l}\text { Tripneustes grazing had a highly significant effect } \\
\text { on seagrass biomass in enclosure treatments. } \\
\text { Lytechinus had a moderate effect on seagrass } \\
\text { biomass. }\end{array}$ & Keller (1983) \\
\hline
\end{tabular}


Table 1 (continued)

\begin{tabular}{|c|c|c|}
\hline Grazer & Seagrass, location, study type & Description of results \\
\hline L. variegatus (U) & $\begin{array}{l}\text { Thalassia testudinum. Biscayne Bay, FL. } \\
\text { Laboratory estimate of sea urchin ingestion } \\
\text { rates and preferences when fed live seagrass } \\
\text { and seagrass detritus. }\end{array}$ & $\begin{array}{l}\text { Urchins ingested decayed leaves at a significantly } \\
\text { higher rate than when fed green leaves. No evi- } \\
\text { dence of a significant preference for decayed } \\
\text { leaves over green ones was found. }\end{array}$ \\
\hline L. variegatus (U) & $\begin{array}{l}\text { Thalassia testudinum. Card Sound, FL. } \\
\text { Observations. }\end{array}$ & $\begin{array}{l}\text { A large population of sea urchins consumed all ben- } \\
\text { thic plants in a several hectare area of Card Sound. }\end{array}$ \\
\hline $\begin{array}{l}\text { Tripneustes gratilla (U), } \\
\text { Salmacis sphaeroides (U) }\end{array}$ & $\begin{array}{l}\text { Thalassia hemprichil. Bolinao, Phillippines. } \\
\text { Field and laboratory measurements of sea urchin } \\
\text { consumption of seagrass biomass. Food prei- } \\
\text { erences for several plant species also examined. }\end{array}$ & $\begin{array}{l}\text { Preferences tests showed Tripneustes chose live } \\
\text { SAV alternative food choices. Salmacis consumed } \\
\text { equal quantities of all plant species. Both urchins } \\
\text { efficiently digested and absorbed seagrass } \\
(>60 \%) \text {. Estumates of total SAV consumption by } \\
\text { both sea urchins was } 240 \text { to } 400 \mathrm{~g} \text { DW } \mathrm{m}^{-2} \mathrm{~d}^{-1} \text {, an } \\
\text { average of } \sim 17 \% \text { of SAV produced with a range } \\
\text { from } 3 \text { to } 100 \% \text { of SAV production. }\end{array}$ \\
\hline
\end{tabular}

Paracentrotus /ividus (U)

Posidonia oceanica. Mediterranean Sea. Field experimentation used to determine grazing impacts on seagrass biomass, shoot density and production.

Astropyga maynifica (U)

Zostera marina. Tomioka Bay, Amakusa, Japan. Eelgrass patch size, density and biomass used to document the impact of a sea urchin aggregation on seagrass density. Urchin gut contents were recorded as well.

Heliocidarss erythrogramma Posidonia australis. Botany Bay, Australia (U)

Tripneustes gratilla (U)

Halophila stipulacea. Sinai, Northem Red Sea and the Jordanian coast of the Gulf of Aqaba. Observational.

Temnopleuris michaelsenii (U)

Cockburn Sound, Warnbro Sound, Australia. Field sampling and seagrass mapping were used to document urchin denudation of a seagrass habitat.

Tectura depicta $(\mathrm{G})$

Littorina sitkana (G),

Margarites helicinus (G),

Lacuna variegata (G). Tel-

messus chieragonus (C), $M$ -

crocottus sellaris (F), Branta

canadensis (W). Anas caro-

linensis (W). Anas acuta (W) weekly along with total leat length. At the of the experiment, plants were harvested and analyzed for biomass (shoot, thizome, root), rates of leaf photosynthesis, respiration, and sucrose enzymes worc measured in loaves and shoots, plus protein and sugar contents. Chlorophyll a was extracted from leaf segments.

Zostera marina. Izembek Lagoon, AK. Sampling and ${ }^{1.2} \mathrm{C}:{ }^{12} \mathrm{C}$ analysis
Source

Montague et al. (1991)

Bach (1979)

Klumpp et al

(1993)

Loss of seagrass biomass was directly proportiona to grazing intensity

Kirkman \& Young (1981)

A seagrass patch was reduced from $\sim 71$ to $<3 \mathrm{~m}^{2}$ in 3 mo by grazing. Urchin stomachs were completely full of seagrass. No other plants were observed. The seagrass standing crop decreased from 7789 to $375 \mathrm{~g} \mathrm{DW}$

Urchins completely denuded 20 ha of seagrass from 1979 to 1982 before being dispersed by a storm.

Urchin aggregations reappeared in late 1982 and an additional 25 ha of Posidonia was lost from 1982 to 1984 . Up to 1987 no regrowth had occurred.

Heavy urchin grazıng was recorded on seagrasses at depths ranging from 5 to $9 \mathrm{~m}$. Grazing on seagrass was subsequently verified by gut content analysis.

In Cockburn Sound, seagrasses were grazed by locally abundant Temnopleuris michaelsenii. Mos heavy damage was localized. Where grazing was heavy, plants had not recovered 2 to 4 yr later. Urchins invaded a second site, reducing remanents of one healthy seagrass meadow to bare sand. Intense grazing was noted in fall of 3 different years. Outbreaks were also reported from a third site, where sea urchins removed all of the leaves in deeper portions of a seagrass bed.

Growth rates, carbon reserves, root proliferation, and net photosynthesis of grazed plants were 50 to $80 \%$ lower than on ungrazed plants. The carbon allocated to the roots of ungrazed plants was $800 \%$ higher for ungrazed plants than for arazed plants. Limpet grazing induced carbon limitation in eelgrass growing in an otherwise light replete environment

Bak \& Nojima (1980)

Larkum \& West (1990)

Lipkin (1979) Bouchon (1980) Hulings \& Kirkman (1982). Jafari \& Mahasneh (1984)

Cambridge et al. (1986)

(1996)

Eelgrass was found to be incorporated into the local food chain through herbivory by at least 7 species.
McConnaughey \& McRoy (1.979) 
Table 1 (continued)

\begin{tabular}{|c|c|c|}
\hline Grazer & Seagrass, location, study type & Description of results \\
\hline Ampithoe spp. (C) & $\begin{array}{l}\text { Syringodum. Fiji. Laboratory determuations } \\
\text { of ingestion rates of manatee grass. }\end{array}$ & $\begin{array}{l}\text { Initially amphipods fed at the top of the leaf. } \\
\text { One day later they made nests from tragments } \\
\text { of grazed grass. Grazing rates ranged from } 1.7 \\
\text { to } 26.4 \mathrm{mg} \text { WW ind. } \mathrm{d}^{-1} \text {. Using a carbon budget } \\
\text { approach, the authors estimated that the amphi- } \\
\text { pods grazed } 1 / 2 \text { of the material produced and } \\
\text { further assimilated } 1 / 2 \text { of it. }\end{array}$ \\
\hline Monocanthus chinensis $(F)$ & $\begin{array}{l}\text { Posidonia oceanica. Quibray Bay, Botany Bay, } \\
\text { New South Wales. Stomach analysis and field } \\
\text { sampling. }{ }^{14} \mathrm{C} \text { labeled seagrass used to assess } \\
\text { seagrass assimilation by fishes. }\end{array}$ & $\begin{array}{l}\text { Gut analysis showed fish ate SAV, along with } \\
5 \text { spp. of algae, crustaceans, and other inverte- } \\
\text { brates. Seagrass and amphipods were most } \\
\text { abundant in fish guts. Microscopic examination of } \\
\text { ingested plant material suggested that plants were } \\
\text { untouched. (i.e. no cell wall damage observed). } \\
\text { However, radioactive labeling showed that } 22 \% \\
\text { of labeled SAV was in the liver and gut wall of the } \\
\text { fish, } 32 \text { to } 33 \% \text { in the feces. The remaining label } \\
\text { may have been in other tissues. This is significant } \\
\text { as tt shows that microscopic examination of the } \\
\text { cell walls does not necessarily provide a complete } \\
\text { picture. The actual \% of SAV production removed } \\
\text { was low. }\end{array}$ \\
\hline $\begin{array}{l}\text { Monacanthus chinensis }(\mathrm{F}) \\
\text { Meuschenia freycineti }(\mathrm{F}) \\
\text { Meuschenia trachylepis }(\mathrm{F})\end{array}$ & $\begin{array}{l}\text { Posidonia australis. Port Hacking, New South } \\
\text { Wales. Field sampling and stomach contents. } \\
\text { The entire fish community in a } 400 \mathrm{~m}^{2} \text { area } \\
\text { of } P \text {. australis was collected twice each in } 2 \\
\text { seasons. Stomachs of all leatherjackets were } \\
\text { dissected and the contents identified. The } \\
\text { relative percentages of food items was deter- } \\
\text { mined. Rectal items were identified using } \\
\text { microscope to determine which items were } \\
\text { used as food. }\end{array}$ & $\begin{array}{l}\text { Leatherjackets dominated the fish communily, } \\
\text { averaging } 26 \% \text { of the number and } 34 \% \text { of the } \\
\text { biomass. Seagrasses ingested were small pieces } \\
\text { leaf material which were covered with epibionts. } \\
M \text {. freycineti consistently bit off pieces in neat } \\
\text { semicircular bites. Juveniles of all speries of fed } \\
\text { principally on encrusting animals listed above } \\
\text { with little seagrass being present. Microscopic } \\
\text { rectal contents from several ind. of each species } \\
\text { found that Posidonia was undigested. }\end{array}$ \\
\hline $\begin{array}{l}\text { Monacanthus ciliatus (F) } \\
\text { Stephanolepis hispidus (F) }\end{array}$ & $\begin{array}{l}\text { Thalassia testudinum. Apalachee Bay, FL. } \\
\text { Field sampling and stomach contents of filefish } \\
\text { collected over a } 9 \text { yr period. }\end{array}$ & $\begin{array}{l}\text { These fish fed on a wide variety of prey; however, } \\
\text { seagrass and invertebrates accounted for } 80 \% \text { of } \\
\text { the stomach contents. As fish grew, the dietary } \\
\text { importance of seagrasses and associated epifauna } \\
\text { increased. Approximately } 1 / 2 \text { of the diet of larger } \\
\text { fishes was Thalassia. The pattern was the same } \\
\text { for both species of filefishes. The incidence of } \\
\text { SAV in the diets of Monocanthus was greatest } \\
\text { in late summer and early fall coincident with } \\
\text { peak SAV productivity. The incidence of SAV } \\
\text { in Stephanilepas increased between summer } \\
\text { and fall. }\end{array}$ \\
\hline
\end{tabular}

Hyporhamphus unifasciatus Ruppla moritima and Halodule wrightii. (F)

Hyporhamphus melanochir (F)

Lagodon rhomboides (F)
Crystal kiver FL. Shallow water fish collected with a bay in approximately $1 \mathrm{~m}$ of water.

Zostera muelleri and Heterozostera tasmanica. Cirb Point, Western Port Bay, and Duck Point, Comer Inlet, Australia. Field sampling and stomach contents.

Zostera marına. Fieid sampling and laboratory bioenergetic and radioactive labeling study Pinfish (>65 $\mathrm{mm} \mathrm{SL}$ ) were fed diets of either eelgrass or frozen grass shrimp. Assimilation efficiency for plants (either eelgrass or algae) and shrimp and labeled seagrass.
Source

Mukai \& Ijima

(1995)

Conacher et al.

(1979)

BeIl et al. (1978)

Clements \&

Livingston (1983)

Volume of SAV in gut $-50 \%$ in large halfbeaks.

art \& Adarms (1973)

During the day green eelgrass tissue was in the guts of $93 \%$ af the fish, making up almost $70 \%$ of the total volume. Insects, amphipods, and shrimp larvae made up most of the remaining food

Amphipods were far more imporiant prey at night. Eelgrass tissue was consumed by $1 / 3$ of $f 1 s h$ and was only $18 \%$ of total volume at night. All eelgrass material in the guts was macerated by pharyngeal teeth. Eelgrass in the foregut was undigested. while material in the hindgut was colorless. Microscopic examination of the material found most plant cells were empty.

Pinfish found to assimilate a substantial portion of the organic material from eelgrass, but with less efficiency than shrimp. Specific growth rates of pintish fed grass shrimp partially substituted with either eelgrass or digestible carbohydrates were not significantly different from growth rates when feeding solely on shrimp. Pinfish appeared to increase feeding rates when offered low calorie seagrass.
Robertson \& Klumpp (1983)

Montgomni: Targett (1992) 
Table 1 (continued)

\begin{tabular}{|c|c|c|c|}
\hline Grazer & Seagrass, location, study type & Description of results & Source \\
\hline $\begin{array}{l}\text { Sparisoma rubripinne, } \\
\text { Sparisoma chrysopterum }\end{array}$ & $\begin{array}{l}\text { Thalassia testudinum. Carrie Bow Cay, Belize. } \\
\text { Field tethering study using clean freshly col- } \\
\text { lected pieces of } T \text {. testudinum blades along } \\
\text { with algal species. }\end{array}$ & $\begin{array}{l}\text { Each study found that herbivorous fishes readily } \\
\text { consumed seagrass leaves but the intensity varied } \\
\text { according to coral reef habitat and depth. Lewis } \\
\text { found that tethered Thalassia was entrely } \\
\text { consumed by } 2 \text { parrotfish - Sparisoma rubripinne } \\
\text { and Sparisoma chrysopterum. Lewis also found } \\
\text { that Thalassia was among the preferred sources } \\
\text { of food during feeding trials. }\end{array}$ & $\begin{array}{l}\text { Hay 1981, Lewis } \\
\text { (1985) }\end{array}$ \\
\hline $\begin{array}{l}\text { Scarus spp. (F), Sparisoma } \\
\text { spp. (F), Acanthurus spp. (F) }\end{array}$ & $\begin{array}{l}\text { Thalassia testudinum, Halodule wrightii. US } \\
\text { Virgin Islands. Field experment, stomach } \\
\text { content and obscrvation. Three separate trans- } \\
\text { plantations of mixed plots } T \text {. testudinum and } \\
H \text {. wrightii were placed into a halo zone next } \\
\text { to a coral reef used to assess the impact of her- } \\
\text { bivores on seagrass abundance. In addition, an } \\
\text { artificial reef was built in a mixed turtlegrass } \\
\text { and } H \text {. wrightii habitat. }\end{array}$ & $\begin{array}{l}\text { Parrotfish totally consumed seagrass patches } \\
\text { transplanted into a halo zone next to a coral reef. } \\
\text { Parrotfish (Scarus and Sparisoma) all scem to feed } \\
\text { to some degree on the grass; Scarus guacamaia } \\
\text { had } 95 \% \text { of the gut volume filled with Halodule. } \\
\text { Acanthurus chiurugis and A. bahamensis had } 40 \\
\text { and } 80 \% \text { gut volume filled with seagrass. }\end{array}$ & Randall (1965) \\
\hline $\begin{array}{l}\text { Scarus guacamia, } \\
\text { Sparisoma radians }(\mathrm{F})\end{array}$ & $\begin{array}{l}\text { Thalassia testudinum. St. Croix, USVI. } \\
\text { Sampling. Seagrass leavos collected and fish } \\
\text { bites marks identified along a transect running } \\
\text { from the base of a coral reef into an adjacent } \\
\text { seagrass habitat. }\end{array}$ & $\begin{array}{l}\text { Leaves collected closest to a reef showed bites } \\
\text { resulting from a population of large parrotfishes } \\
\text { (Scarus guacamia) whereas the stations } 20 \text { and } \\
60 \mathrm{~m} \text { from the reef had bites characteristic of } \\
\text { Sparisoma radians. The station } 4 \mathrm{~m} \text { from the reef } \\
\text { showed mixed feeding. }\end{array}$ & $\begin{array}{l}\text { Ogden \& Zieman } \\
(1977)\end{array}$ \\
\hline $\begin{array}{l}\text { Scarus croicensis }(\mathrm{F}) \text {, } \\
\text { Sparisoma aurofrenatum }(\mathrm{F}) \\
\text { Acanthurus chiurugus }(\mathrm{F}) \\
\text { A. bahianus }(\mathrm{F})\end{array}$ & $\begin{array}{l}\text { Syringodium filiforme and Thalassia tes- } \\
\text { tudinum. San Blas Islands, Panama. Field } \\
\text { tethering study measured both feeding } \\
\text { selectivity and intensity. }\end{array}$ & $\begin{array}{l}\text { Each species of seagrass was heavily grazed but } \\
\text { herbivory on these grasses was variable spatially, }\end{array}$ & Tribble (1981) \\
\hline Scarid and siganid fishes & $\begin{array}{l}\text { Enhalus, Thalassia hemprichi, Halodule } \\
\text { unnervis, Cymodocea rotundata, Syringodium } \\
\text { isoetifolium. Palau, Western Carolina Islands. } \\
\text { Field-based monitonng. }\end{array}$ & $\begin{array}{l}\text { All samples of Thalassia and Cymodocea had bite } \\
\text { marks. At one site approximately } 30 \text { to } 40 \% \text { of } \\
\text { leaves of all species except Enhalus, had at least } 1 \\
\text { bite taken. Enhalus had bite marks on at least } \\
75 \% \text { of blades. }\end{array}$ & $\begin{array}{l}\text { Ogden \& Ogden } \\
(1982)\end{array}$ \\
\hline Trichechus manatus (M) & $\begin{array}{l}\text { Syringodium filiforme. Cape Canaveral, FL. } \\
\text { Field experimentation percent cover, and } \\
\text { aboveground biomass used to document } \\
\text { herbivore impact on seagrass. }\end{array}$ & $\begin{array}{l}\text { Grazıng led to significant reductions in seagrass } \\
\text { coverage, biomass and leaf length. Manatees } \\
\text { were highly aggregated but their distribution was } \\
\text { positıvely correlated with the Syringodium and } \\
\text { Halodule density. }\end{array}$ & $\begin{array}{l}\text { Provancha \& Hall } \\
\text { (1991) }\end{array}$ \\
\hline Dugong dugong $(\mathrm{M})$ & $\begin{array}{l}\text { Halodule uninervis. Nang Bay, Moluccas, } \\
\text { East Indonesia. Observation and biomass } \\
\text { monitonng. }\end{array}$ & $\begin{array}{l}\text { Dugongs were found to remove some } 75 \% \text { of } \\
\text { the belowground blomass in the upper } 4 \text { to } 5 \mathrm{~cm} \\
\text { of sediment. Vegetation biomass recovered to } \\
\text { nearby ambient levels in just } 4 \text { to } 5 \text { mo following } \\
\text { grazing during the wet season, no such recovery } \\
\text { was noted during the dry season. }\end{array}$ & $\begin{array}{l}\text { de longh et al. } \\
\text { (1995) }\end{array}$ \\
\hline Dugrong dugong (M) & $\begin{array}{l}\text { Zostera capricorni, Halophila ovalis and } \\
\text { Halophula uninervis. Moreton Ray, east } \\
\text { Australta. Aerial and boat survevs, monitoring } \\
\text { along with field cxpenments usud to document } \\
\text { dugong grazing on seagrass habitats. }\end{array}$ & $\begin{array}{l}\text { Dugongs appear to spend most of their time } \\
\text { grazing. In one area, shoot density, aboveground } \\
\text { biomass and belowground blomass were reduced } \\
\text { by } 65,73 \text { and } 31 \% \text { respectively over } 3.5 \text { mo. } \\
\text { Grazing impacts were variable, in one area shoot } \\
\text { density was reduced by } 85 \% \text { in } 12 \mathrm{~d}, 95 \% \text { in } 17 \% \\
\text { In another area biomass was reduced by } 96 \% \\
\text { (aboveground) and } 71 \% \text { belowground. }\end{array}$ & Preen (1995) \\
\hline Chelonla mydas (R) & $\begin{array}{l}\text { Thalassia testudinum. Great Iguana, Bahamas. } \\
\text { Field-based observations and bioenergetic } \\
\text { study. A } 3 \text { ha area of turtlegrass was } \\
\text { impounded along with } 12 \text { turtles and changes } \\
\text { in seagrass biomass were noted. }\end{array}$ & $\begin{array}{l}\text { Turtles grazed grass blades by biting the lower } \\
\text { parts of the leaves and allowing the upper portion } \\
\text { to float away, creating a patch of closely cropped } \\
\text { patches with leaves averaging } 2.5 \mathrm{~cm} \text { in length. } \\
\text { The grazed areas were recropped while adjacent } \\
\text { stands of tall blades remained untouched. There } \\
\text { were no sharp boundaries between grazed and } \\
\text { ungrazed areas. }\end{array}$ & Bjorndal (1980) \\
\hline $\begin{array}{l}\text { Diadema antillarum }(\mathrm{U}) \\
\text { Chelonia migdas }(\mathrm{R})\end{array}$ & $\begin{array}{l}\text { Thalassia testudinum. St. Crolx, USVl. Field } \\
\text { experiments where changes in seagrass growth } \\
\text { and biomass were recorded along a grazing } \\
\text { gradient. }\end{array}$ & $\begin{array}{l}\text { Turtle grazing had a significant negative impact } \\
\text { on seagrass production. Urchins were ineffective } \\
\text { in controlling the abundance of seagrass. How- } \\
\text { ever, urchin grazing did increase the rate at which } \\
\text { seagrass biomass turned over within enclosures. }\end{array}$ & $\begin{array}{l}\text { Zieman et al. } \\
\text { (1984) }\end{array}$ \\
\hline
\end{tabular}


Unlike many species marine macroalgae and phytoplankton which are wholly exposed to marine grazers and often totally consumed by them (cf. Hay \& Steinberg 1992 but see Steneck 1988 and Steneck \& Dethier 1994), the stored reserves and sites of nutrient uptake for many seagrasses are located in a belowground 'refuge' which is not accessible to most grazers. This belowground refuge represents a stabilizing influence that allows seagrasses to persist where herbivory is intense and can, depending on the season, allow seagrasses to recover rapidly to levels that equal or exceed those in nearby ungrazed plots. What is unclear is what factors control seagrass responses to grazing, how long seagrasses can sustain higher levels of production post-grazing, and how they affect rates of energy flow through nearshore food webs.

\section{FOOD WEB IMPORTANCE OF SEAGRASS HERBIVORY}

We know of only a few attempts to estimate the amount of seagrass production directly entering nearshore food webs (Greenway 1976, 1995, Nienhaus \& Groenendijk 1986, Klumpp et al. 1993). From these studies it has been estimated that somewhere between -3 and $100 \%$ of seagrass net primary production enters food webs via the grazing pathway. All have relied on short-term laboratory measurements and anecdotal field observations to identify the levels of seagrass production entering local food webs. While laboratorybased efforts provide us with testable hypotheses, relying solely on such approaches allows only a rough estimate of the amount of material being consumed directly at a particular site. Accurately determining the density and the time spent grazing in a location, which would be required for such an approach, is likely to be limited to the amount of time a diver can spend underwater and involves an intensive effort. Moreover, in the case of vertebrate grazers, estimates may be low as fishes may avoid areas while divers are present. Such estimates must also be conducted seasonally as many of the vertebrate grazers exhibit seasonal migrations. In addition, laboratory approaches do not include the possibility that rates of plant regrowth following grazing can exceed those of ungrazed areas, which could lead to large underestimates of the amount of material grazed by these herbivores. This has been recognized to be significant in many ecosystems (Lehman \& Scavia 1982, Cargill \& Jeffries 1984, Bianchi 1988, Williams \& Carpenter 1988, Littler et al. 1995, McNaughton et al. 1996), and more recently also shown to be substantial in seagrass ecosystems (Valentine \& Heck 1991, SandJensen et al. 1994, Valentine et al. 1997). To date, there have been no attempts to estimate the quantitative im- pact of such compensatory responses to herbivory in seagrass systems. And while it has been recognized that we need to develop a better understanding of the role of sediment porewater nutrient concentrations and rhizome carbohydrate stores in determining seagrass production (cf. Zieman et al. 1984, Valentine et al. 1997), there have been no sustained experiments that have simultaneously considered the roles of each of these factors, how they could be influenced by herbivory, or what impact they may have on the transfer of energy to nearshore food webs.

In summary, while grazing on seagrasses is undoubtedly reduced in a historical context, herbivores still have significant effects on aboveground seagrass biomass in many areas (see Table 1 for a list of publications documenting grazing on seagrasses). Most importantly, previous studies of seagrass herbivory have not measured seagrass leaf turnover rates, which are essential to accurately estimate the amount of seagrass production actually consumed by herbivores (cf. Zieman et al. 1984, Sand-Jensen et al. 1994, Valentine et al. 1997). To date, there have been precious few field experiments which have simultaneously considered the multiple controlling factors that determine just how much energy actually flows from seagrasses to herbivores in nearshore food webs. We contend that the currently accepted hypothesis that herbivory plays a small role in the energetics of seagrass habitats and nearby coastal ecosystems needs to be reexamined using controlled field manipulations. Such studies will provide estimates of the amount of seagrass production directly entering nearshore food webs, and they will improve our understanding of the factors that control spatial and temporal variability of seagrass herbivory.

Acknowledgements. We thank Drs R. Aronson and B. Steneck and Ms Michele Eilers for their constructive criticisms of this manuscript. This work was supported by the Biological Oceanography Program of the National Science Foundation (Grant No. OCE-9102217), the National Science Foundation (Alabama) Experimental Program to Stimulate Competitive Research (R11-8996152), and the National Undersea Research Center (UNCW \#9537). MESC contribution No. 291.

\section{LITERATURE CITED}

Anderson PK, Birtles A (1978) Behavior and ecology of the Dugong dugong (Sirenia): observations in Shoalwater and Cleveland Bays, Queensland. Aust Wild Res 5:11-23

Bach SD (1979) Standing crop, growth, and production of calcareous Siphonales (Chlorophyta) in a south Florida lagoon. Bull Mar Sci 29:191-201

Backman TW, Barilotti DC (1976) Irradiance reduction: effects on standing crop of the eelgrass Zostera marina in a coastal lagoon. Mar Biol 34:33-40

Bak HP, Nojima S (1980) Immigration of a tropical sea urchin, Astropyga radiata (Leske) in a temperate eelgrass, Zostera 
marina L. patch: its feeding habit and grazing effect on the patch. Publ Amakusa Mar Biol Lab 5:153-169

Baldwin JR, Lovvorn JR (1994) Expansion of seagrass habitat by the exotic Zostera japonica and its use by dabbling ducks and brant in Boundary Bay, British Columbia. Mar Ecol Prog Ser 103:119-127

Bell JD, Burchmore JJ, Pollard DA (1978) Feeding ecology of three sympatric species of leatherjackets (Pisces: Monacanthidae) from a Posidonia seagrass habitat in New South Wales. Aust J Mar Freshw Res 29:631-643

Bianchi T (1988) Feeding ecology of subsurface depositfeeder Leitoscoloplus fragilis Verrill. I. Mechanisms affecting particle availability on intertidal sandflat. J Exp Mar Biol Ecol 115:79-97

Bjorndal KA (1980) Nutrition and grazing behavior of the green turtle Chelonia mydas. Mar Biol 56:147-156

Bouchon C (1980) Quantitiative study of the scleractinian coral communities of the jordanian coast (Gulf of Aqaba, Red Sea): preliminary results. Tethys 9:243-246

Cambridge ML, Chiffings AW, Brittan C, Moore L, McComb AJ (1986) The loss of seagrass in Cockburn Sound, Western Australia. 2. Aquat Bot 24:269-285

Camp DK, Cobb SP, Van Breedfield JV (1973) Overgrazing of seagrasses by a regular urchin, Lytechinus variegatus. BioSci 23:37-38

Cargill SM, Jeffries RL (1984) Nutrient limitations of primary production in a sub-arctic salt-marsh. J Appl Ecol 21: $657-660$

Carpenter RC (1986) Partitioning herbivory and its effects on coral reef algal communities. Ecol Monogr 56:345-363

Carr SA, Adams CA (1973) Food habits of juvenile marine fishes occupying seagrass beds in the estuarine zone near Crystal River, Florida. Trans Am Fish Soc 102:511-540

Cebrián J, Duarte CM, Marbà N (1996a) Herbivory on the seagrass Cymodocea nodosa (Ucria) Acherson in contrasting Spanish Mediterranean habitats. J Exp Mar Biol Ecol 204:103-111

Cebrián J, Duarte CM, Marbà N, Enríquez S, Gallegos M Olesen B (1996b). Herbivory on Posidonia oceanica: magnitude and variability in the Spanish Mediterranean. Mar Ecol Prog Ser 130:147-155

Charman $\mathrm{K}$ (1977) The grazing of Zostera by wildfowl in Britain. Aquaculture 12:229-233

Charman K (1979) Feeding ecology and energetics of the dark-bellied brent goose (Branta bernicla) in Essex and Kent. In: Jefferies RL, Davys AJ (eds) Ecological processes in coastal environments. Blackwell Scientific Publications, Oxford, p 451-465

Clements WH, Livingston RJ (1983) Overlap and pollutioninduced variability in the feeding habits of filefish (Pisces: Monacanthidae) from Apalachee Bay. Florida. Copeia 1983:331-338

Conacher MJ, Lanzig WJR, Larkum AWD (1979) Ecology of Botany Bay. II. Aspects of the feeding ecology of the fanbellied leatherjacket Monacanthus chinensis (Pisces: Monacanthidae) in Posidonia australis seagrass beds in Quibray Bay, Botany Bay, New South Wales. Aust J Mar Freshw Res 30:387-400

Dayton PK, Thrush SF, Agardy MT, Hofman RF (1995) Environmental effects of marine fishing Aquat Conserv Mar Freshw Ecosyst 5:205-232

de Iongh $\mathrm{HH}$, Wenno BJ, Meelis E (1995) Seagrass distribution and seasonal biomass changes in relation to dugong grazing in the Moluccas: East Indonesia. Aquat Bot 50:1-19

Demot WR, Kerfoot WC (1982) Competition among cladocerans: nature of the interaction between Bosmina and Daphnia. Ecology 63:1949-1966
Dennison WC, Alberte RS (1985) Photosynthetic responses of Zostera marina L (eelgrass) to in situ manipulations of light intensity. Oecologia 55:137-144

Duarte CM (1990) Seagrass nutrient content. Mar Ecol Prog Ser 67:201-207

Dubin RE, Baker JD (1982) Two types of cover-seeking behavior at sunset by the princess parrotfish. Scarus taeniopterus, at Barbados, West Indies. Bull. Mar Sci 32: $572-583$

Fenchel $T(1970)$ Studies on the decomposition of organic detritus derived from the turtlegrass Thalassia testudinum. Limnol Oceanogr 15:14-20

Fenchel T (1977) Aspects of the decomposition of seagrasses. In: McRoy CP, Helferich C (eds) Seagrass ecosystems: a scientific perspective. Marcel Dekker Inc, New York, p $123-145$

Fourqurean JW, Zieman JC, Powell GVN (1992) Phosphorus limitation of primary production in Florida Bay: evidence from C:N:P ratios of the dominant seagrass Thalassia testudinum. Limnol Oceanogr 37:162-171

Fry B, Parker PL (1979) Animal diet in Texas seagrass meadows: ${ }^{13} \mathrm{C}$ evidence for the importance of benthic plants. Estuar Coast Mar Sci 8:499-509

Fry B, Luthes R, Northam M, Parker PL (1982) A ${ }^{13} \mathrm{C} /{ }^{12} \mathrm{C}$ comparison of food webs in Caribbean seagrass meadows and coral reefs. Aquat Bot 14:389-398

Gaines SD, Lubchencho J (1982) A unified approach to marine plant-herbivore interactions. II. Biogeography. Annu Rev Ecol Syst 13:111-138

Greenway M (1976) The grazing of Thalassia testudinum in Kingston Harbour, Jamaica. Aquat Bot 2:117-126

Greenway M (1995) Trophic relationships of macrofauna within a Jamaican seagrass meadow and the role of the echinoid Lytechinus variegatus (Lamarck). Bull Mar Sci 56:719-736

Handley $F$ (1984) Time-budgeting and foraging strategy of the stoplight parrotfish Sparisoma viride Bonnaterre, in Jamaica. J Exp Mar Biol Ecol 83:159-177

Harrison PG, Mann KH (1975) Chemical changes during the seasonal cycle of growth and decay in eelgrass (Zostera marina) on the Atlantic Coast of Canada. J Fish Res Bd Can 32:615-621

Hay ME (1981) Spatial patterns of grazing intensity on a Caribbean barrier reef: herbivory and algal distribution. Aquat Bot 11:97-109

Hay ME (1984a) Patterns of fish and sea urchin grazing on Caribbean coral reefs: are previous results typical? Ecology 65:446-454

Hay ME (1984b) Predictable spatial escapes from herbivory: how do these affect the evolution of herbivore resistance in tropical marine communities. Oecologia 64:396-407

Hay ME (1997) The ecology and evolution of seaweedherbivore interactions on coral reefs. Proc 8 th Int Coral Reef Symp 1:23-32

Hay ME, Steinberg PD (1992) The chemical ecology of plantherbivore interactions in marine versus terrestrial communities. In: Rosenthal $G$, Berenbaum $M$ (eds) Herbivores: their interactions with secondary plant metabolites, 2nd edn, Vol 2. Academic Press, New York, p 372-413

Heck KL, Valentine JF (1995) Sea urchin herbivory: evidence for long-lasting effects in subtropical seagrass meadows. $J$ Exp Mar Biol Ecol 189:205-217

Heinsohn GE, Birch WR (1972) Foods and feeding habits of the dugong, Dugong dugong, (Erxleben), in northern Queensland, Australia. Mammalia 36:414-422

Heinsohn GE, Spain GE, Anderson PK (1976) Populations of dugongs (Mammalia: Sirenia). Aerial surveys over the 
inshore waters of tropical Australia. Biol Conserv 8:21-23

Hulings NC, Kirkman $H$ (1982) Further observations and data on seagrasses along the Jordanian and Saudi Arabian coasts of the Gulf of Aqaba. Tethys 10:281-220

Jacobs RPW, den Hartog MC, Braster BF, Carriere FC (1981) Grazing of the seagrass Zostera noltii by birds at Terschelling (Dutch Wadden Sea). Aquat Bot 10:241-259

Jacobsen D. Sand-Jensen K (1994) Invertebrate herbivory on the submerged macrophyte Potamogeton perfoliatus in a Danish Stream. Freshw Biol 31:43-52

Jackson JBC (1997) Reefs since Columbus. Proc 8th Int Coral Reef Symp 1:97-106

Jafari RD, Mahasneh RM (1984) The effect of seagrass grazing on the sexual maturity of the sea urchin Tripneustes gratilla in the Gulf of Aqaba (Jordan). Dirasat 14:127-136

Jernakoff P, Brearley A, Nielsen J (1996) Factors affecting grazer-epiphyte interactions in temperate seagrass meadows. In: Ansell AD, Gibson RN, Barnes M (eds) Oceanography and marine biology: an annual review, Vol 34. UCL Press, London, p 109-162

Keller BD (1983) Coexistence of sea urchins in seagrass meadows: an experimental analysis of competition and predation. Ecology 64:1581-1598

Kikuchi $T(1980)$ Faunal relationships in temperate seagrass beds. In: Phillips RC, McRoy CP (eds) Handbook of seagrass biology: an ecosystem perspective. Garland STPM Press, New York, p 153-172

Kikuchi T, Peres JM (1977) Consumer ecology of seagrass beds. In: McRoy CP, Helfferich $C$ (eds) Seagrass ecosystems: a scientific perspective. Marcel Dekker Inc, New York, p 147-194

Kiørboe T (1980) Distribution and production of submerged macrophytes in Tipper Grund (Ringkøbing Fjord, Denmark), and the impact on grazing. J Appl Ecol 17:675-687

Kirkman $H_{1}$ Reid DD (1979) A study of the role of seagrass Posidonia australis in the carbon budget of an estuary. Aquat Bot 7:173-183

Kirkman H, Young PC (1981) Measurement of health, and echinoderm grazing on Posidonia oceanica (L.) Delile. Aquat Bot 10:329-338

Klumpp DW, Nichols PD (1983a) Nutrition of the southern sea garfish Hyporhamphus melanochiri gut passage rate and daily consumption of two food types and assimilation of seagrass components. Mar Ecol Prog Ser 12:209-216

Klumpp DW, Nichols PD (1983b) A study of food chains in seagrass communities. 2. Food of the rock flathead Platycephalous laevigatus Cuvier, a major predator in a Posidonia australis seagrass bed. Aust J Mar Freshw Res 34 $745-754$

Klumpp DW, Van der Walk A (1984) Nutritional quality of seagrasses Posidonia oceanica and Heterozostera tasmanica: comparisons between species and stages of decomposition. Mar Biol Lett 5:67-83

Klumpp DW, Salita-Espinosa JT, Fortes MT (1993) Feeding ecology and trophic role of sea urchins in a tropical seagrass community. Aquat Bot 45:205-229

Lalli CM, Parsons TR (1993) Biological oceanography. An introduction. Pergamon Press, New York

Lanyon JM, Limpus CJ, Marsh H (1989) Dugongs and turtles: grazers in the seagrass system. In: Larkum AWD, McComb AJ, Shepard SA (eds) Biology of seagrasses: a treatise on the biology of seagrasses with special reference to the Australian region. Elsevier, Amsterdam, p $610-634$

Larson B, Vadas RL, Keser M (1980) Feeding and nutritional ecology of the sea urchin Strongylocentrotus droebachiensis in Maine, USA. Mar Biol 59:49-62
Larkum AWD, West RJ (1990) Long-term changes of seagrass meadows in Botany Bay, Australia. Aquat Bot 37:55-70

Lawrence JM (1975) On the relationships between marine plants and sea urchins. Oceanogr Mar Biol Annu Rev 13: $213-286$

Lehman J, Scavia D (1982) Microscale patchiness of nutrients in plankton communities. Science 216:729-730

Lewis SM (1985) Herbivory on coral reefs: algal susceptible to herbivorous fishes. Oecologia 65:370-375

Lewis SM, Wainwright PC (1985) Herbivore abundance and grazing intensity on a Caribbean coral reef. J Exp Mar Biol Ecol 87:215-228

Lilly GR (1975) The influence of diet on the growth and energetics of the tropical sea urchin. Tripneustes ventricosus (Lamarck). PhD dissertation, Univ Of British Columbia, Vancouver

Lipkin $Y$ (1975) Food of the Red Sea Dugong (Mammalia: Sirenia) from Sinai. Is J Zool 24:81-98

Lipkin Y (1979) Quantitative aspects of seagrass communities particularly of those dominated by Halophila stipulacea, in Sinai (Northern Red Sea). Aquat Bot 7:119-128

Littler MM, Littler DS, Taylor PR (1995) Selective herbivore increases biomass of its prey: a chiton-coralline reefbuilding association. Ecology 76:1666-1681

Lobel PS, Ogden JC (1981) Foraging by herbivorous parrotfish Sparisoma radians. Mar Biol 64:173-183

Lowe EF, Lawrence JM (1976) Absorption efficiencies of Lytechinus variegatus (Lamarck) (Echinodermata: Echinoidea) for selected marine plants. J Exp Mar Biol Ecol 21 223-234

Lubchencho J, Gaines SD (1981) A unified approach to marine plant-herbivore interactions. I. Populations and communities. Annu Rev Ecol Syst 12:405-437

Lynch M, Shapiro J (1981) Predation, enrichment, and phytoplankton community structure. Limnol Oceanogr 29: $243-252$

MacIntyre IG, Graus RR, Reinthal PN, Littler MM, Littler DS (1987) The barrier reef sediment apron: Tobacco Reef, Belize. Coral Reefs 6:1-12

Madsen J (1988) Autumn feeding ecology in the Danish Wadden Sea, and impact of food supplies and shooting on movement. Dan Rev Game Biol 13:1-32

Mallin MA, Paerl HW (1994) Planktonic trophic transfer in an estuary: seasonal, diel, and community structure effects Ecology 75:2168-2184

Marguillier S, van der Velde G, Dehairs F, Hemminga MA, Rajagopal S (1997) Trophic relationships in an interlinked mangrove-seagrass ecosystem as traced by $\delta^{13} \mathrm{C}$ and $\delta^{15} \mathrm{~N}$. Mar Ecol Prog Ser 151:115-1.21

Marsh H, Channells PW, Heinsohn GE, Morrissey J (1982) Analysis of stomach contents of dugongs from Queensland. Aust Wildl Res 9:55-67

McAfee ST, Morgan SG (1996) Resource use by five sympatric parrotfishes in the San Blas Archipelago, Panama. Mar Biol 125:427-437

McCauley E, Briand F (1979) Zooplankton grazing and phytoplankton species richness: field tests of the predation hypothesis. Limnol Oceanogr 24:243-252

McConnaughey T, McRoy CP $(1979){ }^{13} \mathrm{C}$ label identifies eelgrass (Zostera marina) carbon in an Alaskan estuarine food web. Mar Biol 53:263-269

McGlathery K (1995) Nutrient and grazing influences on subtropical seagrass community. Mar Ecol Prog Ser 122 : $239-252$

McNaughton SJ, Milchunas DG, Frank DA (1996) How can net primary productivity be measured in grazing ecosystems? Ecology 77:974-877 
Michot TC, Chadwick PC (1994) Winter biomass and nutrient values of three seagrass species as potential food sources for redheads (Aythya americana Eyton) in Chandeleur Sound, Louisiana. Wetlands 14:276-283

Mitchell CA, Custer TA, Zwank PJ (1994) Herbivory on shoalgrass by wintering redheads in Texas. J Wildl Mgmt 58: $131-141$

Moore HB, Jutare T, Bauer JC (1963) The biology of Lytechinus variegatus. Bull Mar Sci 13:23-53

Montague JR, Aguinaga JA, Ambrisco KL, Vassil DL, Collazo $W$ (1991) Laboratory measurement of ingestion rate for the sea urchin Lytechinus variegatus (Lamarck). Fla Scient $54: 129-134$

Montgomery JLM, Targett TE (1992) The nutritional role of seagrass in the omnivorous fish Lagodon rhomboides (L.). J Exp Mar Biol Ecol 158:37-57

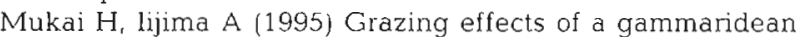
Amphipoda, Ampithoe sp., on the seagrass, Syringodium isoetifolium, and epiphytes in a tropical seagrass bed of Fiji. Ecol Res 10:243-257

Nichols P, Klumpp DW, Johns RB (1985) A study of food chains in seagrass communities. 3. Stable carbon isotope ratios. Aust J Mar Freshw Res 36:683-690

Nienhaus PH, Groenendijk AM (1986) Consumption of eelgrass (Zostera marina) by birds and invertebrates: an annual budget. Mar Ecol Prog Ser 29:29-35

Nienhaus PH, Van Ierland ET (1978) Consumption of eelgrass, Zostera marina, by birds and invertebrates during the growing season in Lake Grevekingen (SW Netherlands). Neth J Sea Res 12:180-194

Nietschmann B (1990) Conservation by conflict in Nicaragua Nat Hist 99:42-49

Nietschmann B, Nietschmann J (1981) Good dugong, bad dugong and bad turtle, good turtle. Nat Hist 90:54-63

Nishiwaki M, Marsh H (1985) The dugong. In: Ridgeway $\mathrm{SH}$ Harrison RJ (eds) Handbook of marine mammals, Vol 3 Academic Press, London, p 1-31

Nojima S, Mukai H (1990) Feeding habits of fishes associated with a tropical seagrass bed in Papua New Guinea. Publ Amakusa Mar Biol Lab 10:175-186

Ogden JC (1976) Some aspects of herbivore-plant relations in Caribbean reefs and seagrass beds. Aquat Bot 2: $103-116$

Ogden JC (1980) Faunal relationships in Caribbean seagrass beds. In: Phillips RC, McRoy CP (eds) Handbook of seagrass biology. An ecosystem perspective. Garland STPM Press, New York, p 173-198

Ogden JC, Brown R, Salesky N (1973) Grazing by the echinoid Diadema antillarum Philippi: formation of halos around West Indian patch reefs. Science 182:715-717

Ogden JC, Ogden NB (1982) A preliminary study of two representative seagrass communities in Palau, Western Caroline Islands (Micronesia). Aquat Bot 12:229-244

Ogden JC, Zieman JC (1977) Ecological aspects of coral reefseagrass bed contacts in the Caribbean. Proc 3rd Int Coral Reef Symp 1:377-382

Ogden JC, Robinson L, Whitlock K, Daganhardt H, Cebula R (1983) Diel foraging patterns in juvenile green turtles (Chelonia mydas L.) in St. Croix United States Virgin Islands. J Exp Mar Ecol 66:199-205

Patriquin DG (1972) The origin of nitrogen and phosphorus for growth of the marine angiosperm Thalassia testudinum. Mar Biol 15:35-46

Patriquin DG (1975) 'Migration' of blowouts in seagrass beds at Barbados and Carriacou, West lndies, and its ecological and geological implications. Aquat Bot 1:163-189

Pinto L. Punchihewa $\Lambda$ (1996) Utilisation of mangroves and seagrasses by fishes in the Negombo Estuary, Sri Lanka Mar Biol 126:333-345

Polunin NVC (1996) Trophodynamics of reef fisheries productivity. In: Polunin NVC, Roberts CM (eds) Reef fisheries Chapman and Hall, London, p 113-135

Porter KG (1973) Selective grazing and differential digestion by zooplankton. Nature 224:179-180

Porter KG (1977) The plant-animal interface in freshwater ecosystems. Am Nat 65:159-170

Portig AA, Mathers RG, Montgomery WI, Govier RN (1994) The distribution and utilisation of Zostera species in Strangford Lough, Northern lreland. Aquat Bot 47:317-328

Powell GVN, Kenworthy WJ, Fourqurean JW (1989) Experimental evidence of nutrient limitation of seagrass growth in a tropical estuary with restricted circulation. Bull Mar Sci 44:324-340

Preen A (1995) Impacts of dugong foraging on seagrass habitats: observational and experimental evidence for cultivation grazing. Mar Ecol Prog Ser 124:201-213

Provancha J, Hall CR (1991) Observations of associations between seagrass beds and manatees in east central Florida. Fla Scient 54:87-98

Randall JE (1965) Grazing effect on sea grasses by herbivorous reef fishes in the West Indies. Ecology 46: $255-260$

Randall JE (1967) Food habits of reef fishes of the West Indies Stud Trop Oceanogr 5:665-847

Rice DL (1982) The detritus nitrogen problem: new observations and perspectives from organic geochemistry. Mar Ecol Prog Ser 9:153-162

Robertson AI, Klumpp DW (1983) The southern sea-garfish Hyporamphus melanochir a diurnal herbivore and nocturnal carnivore. Mar Ecol Prog Ser 10:207-213

Sand-Jensen K, Jacobsen D, Duarte CM (1994) Herbivory and resulting plant damage. Oikos 69:545-549

Short FT (1987) Effects of sediment nutrients on seagrasses: literature review and mesocosm experiment. Aquat Bot 27:41-57

Short FT, Montgomery J, Zimmerman CF, Short CA (1993) Production and nutrient dynamics of a Syringodium filiforme Kutz seagrass bed in Indian River Lagoon. Florida. Estuaries 16:323-334

Spain AV, Heinsohn GE (1973) Cyclone associated feeding changes in the dugong (Mammalia: Sirenia). Mammalia 37:678-680

Springer VG, McErlean AJ (1962) Seasonality of fishes on a South Florida shore. Bull Mar Sci 12:39-60

Steneck RS (1988) Herbivory on coral reefs: a synthesis. Proc 6th Int Coral Reef Symp 1:37-49

Steneck RS, Dethier MN (1994) A functional group approach to the structure of algal-dominated communities. Oikos 69:476-498

Tertschnig WP (1989) Diel activity patterns and foraging dynamics of the sed urchin Tripneustes ventricosus in a tropical seagrass community and a reef environment. (Virgin Islands) PSZN I: Mar Ecol 10:3-21

Thayer GW, Bjorndal KA, Ogden JC, Williams SL, Zieman JC (1984) Role of larger herbivores in seagrass communities. Estuaries 7:351-376

Thayer GW, Engel DW, La Croix MW (1977) Seasonal distribution and changes in the nutritive quality of living and detrital fractions of Zostera marina L. J Exp Mar Biol Ecol 30:109-127

Thayer GW, Parker PL, LaCroix MW, Fry B (1978) The stable carbon isotope ratio of some components of an eelgrass, Zostera marina, bed. Oecologia 35:1-12

Thom RM, Albright RG (1990) Dynamics of benthic vegeta- 
tion standing-stock, irradiance, and water properties in central Puget Sound. Mar Biol 104:129-141

Thompson JM (1959) Some aspects of the ecology of Lake Macquarie, NSW, with regard to an alleged depletion of fish. IX. The fishes and their food. Aust J Mar Freshw Res 10:365-374

Tomasko DA, Dawes CJ (1989) Evidence for physiological integration between shaded and unshaded short shoots of Thalassia testudinum. Mar Ecol Prog Ser 54:299-305

Tominson PB, Vargo GA (1966) On the morphology and anatomy of the turtlegrass, Thalassia testudinum (Hydrocharitaceae) I. Vegetative morphology. Bull Mar Sci 16: $748-761$

Tribble GW (1981) Reef-based herbivores and the distribution of two seagrasses (Syringodium filiforme and Thalassia testudinum) in the San Blas Islands (Western Caribbean). Mar Biol 65:277-281

Tubbs CR, Tubbs JM (1983) The distribution of Zostera and its exploitation by wildfowl in the Solent, Southern England. Aquat Bot 15:223-239

Vadas RL, Fenchel T, Ogden JC (1982) Ecological studies on the sea urchin Lytechinus variegatus and the algalseagrass commuities of the Miskito Cays, Nicaragua. Aquat Bot 14:139-150

Valiela I (1995) Marine ecological processes, 2nd edn. Springer Verlag, New York

Valentine JF, Heck KL Jr (1991) The role of sea urchin herbivory in regulating subtropical seagrass meadows: evidence from field manipulations in the northern Gulf of Mexico. J Exp Mar Biol Ecol 154:215-230

Valentine JF, Heck KL, Busby J, Webb D (1997) Experimental evidence that herbivory can increase shoot density in a subtropical turtlegrass (Thalassia testudinum) meadow Oecologia 112:193-200

Vanni MJ (1987a) Effects of food availability and fish predation on a zooplankton community Ecol Monogr 57:61-88

Vanni MJ (1987b) Effects of nutrients and zooplankton size on the structure of a phytoplankton community Ecology 68: $624-635$

Verlaque $M$, Nedelec $H$ (1983) Note preliminaire sur les rela-

Editonial responsibility: Kenneth Tenore (Contributing Editor), Solomons, Maryland, USA tions biotiques Paracentrotus lividus (LMK.) et herbier de posidonies. Rapp PV Réun Comm Int Explor Sci Mer 28 $157-158$

Vicente VP, Rivera JA (1982) Depth limits of the seagrass Thalassia testudinum (König) in Jobos and Guayanilla Bays, Puerto Rico. Caribb J Sci 17:73-79

Wilkins WE (1982) Waterfowl utilization of a submerged vegetation (Zostera marina and Ruppia maritima) bed in the lower Chesapeake Bay. MSc thesis, College of William and Mary, Williamsburg

Williams SL, Carpenter RC (1988) Nitrogen-limited primary productivity of coral reef algal turfs: potential contribution of ammonium excreted by Diadema antillarum. Mar Ecol Prog Ser 47:145-152

Winn HE, Bardach JE (1960) Some aspects of the comparative biology of parrotfishes at Bermuda. Zoologica 45:29-34

Winn HE, Salomon M, Roberts N (1964) Sun compass orientation by parrotfishes. Z Tierpsychol 21:798-812

Zieman JC (1975) Quantitative and dynamic aspects of the ecology of turtle grass Thalassia testudinum. In: Cronin L (ed) Estuarine research, Vol 1, Chemistry, biology and the estuarine system. Academic Press, New York, p 541-562

Zieman JC (1983) Food webs in tropical seagrass systems. In: Ogden JC, Gladfelter EH (eds) Coral reefs, seagrass meadows and mangroves: their interaction in the coastal zones of the Caribbean. UNESCO Rep Mar Sci 23:80-86

Zieman JC, Zieman RT (1989) The ecology of the seagrass meadows of the west coast of Florida: a community profile. Biol Rep 85(7.25)

Zieman JC, Iverson RL, Ogden JC (1984) Herbivory effects on Thalassia testudinum leaf growth and nitrogen content. Mar Ecol Prog Ser 15:151-158

Zimmerman RC, Livingston RJ (1976) Effects of the kraft-mill effluents on benthic macrophyte assemblages in a shallow bay system (Apalachee Bay, North Florida, USA). Mar Biol $34: 297-312$

Zimmerman RC, Kohrs DG, Alberte RS (1996) Top-down impact through a bottom-up mechanism: the effect of limpet grazing on growth, productivity and carbon allocation of Zostera marina L. (eelgrass). Oecologia 107:560-567

Submitted: November 10, 1997; Accepted: August 11, 1998 Proofs received from author(s): December 14, 1998 